\title{
UNA FE A LA LUZ DE LA ILUSTRACIÓN. EL FRUSTRADO MODELO DE RELIGIOSIDAD DE PABLO DE OLAVIDE PARA LAS NUEVAS POBLACIONES DE SIERRA MORENA Y ANDALUCÍA (1767-1776)
}

\author{
POR \\ ADOLFO HAMER FLORES ${ }^{1}$ \\ Universidad Loyola Andalucía \\ Y \\ FRANCISCO JOSÉ PÉREZ FERNÁNDEZ ${ }^{2}$ \\ Grupo de Investigación HUM-155, Universidad de Jaén
}

RESUMEN

La controvertida trayectoria biográfica de Pablo de Olavide es bien conocida gracias a varios trabajos de investigación que han analizado gran parte de su vida y sus acciones. Su afán reformista, influenciado por las ideas y corrientes de la llustración, acabó en una sentencia inquisitorial condenatoria, pero, afortunadamente, este proceso nos permite conocer su particular modo de entender la religión. De ahí que el objetivo de este trabajo sea el de realizar una aproximación al modelo de religiosidad que Olavide trató de implantar en esas poblaciones, así como al rechazo o resistencia que este generó en el clero y las clases populares.

PALABRAS CLAVE: Ilustración; Pablo de Olavide; religiosidad; siglo XVIII.

\section{A FAITH IN THE LIGHT OF THE ENLIGHTENMENT. THE FRUSTRATED MODEL OF RELIGIOSITY OF PABLO DE OLAVIDE FOR THE NEW SETTLEMENTS OF SIERRA MORENA AND ANDALUSIA (1767-1776)}

\section{ABSTRACT}

The controversial biographical trajectory of Pablo de Olavide is well known thanks to several research works that have analyzed much of his life and his actions. His reformist zeal, influenced by the ideas and currents of the Enlightenment, ended in a condemnation of the Inquisition, but, fortunately, this process allows us to know his particular way of understanding religion. Hence, the objective of this work is to make an approximation to the religiosity model that Olavide tried to implant in those populations, as well as the rejection or resistance that this generated in the clergy and the popular classes.

KEY WORDS: Enlightenment; Pablo de Olavide; religiosity; $18^{\text {th }}$ century.

Cómo CITAR ESTE ARTículo / CITATION: Hamer Flores, Adolfo y Francisco José Pérez Fernández. 2021. «Una fe a la luz de la Ilustración. El frustrado modelo de religiosidad de Pablo de Olavide para las Nuevas Poblaciones de Sierra Morena y Andalucía (1767-1776)». Hispania Sacra LXXIII, 147: 221-233. https://doi.org/10.3989/hs.2021.019

Recibido/Received 31-10-2019

Aceptado/Accepted 29-09-2020

ahamer@uloyola.es / ORCID iD: https://orcid.org/0000-0001-5216-5470

fjperezfdez@telefonica.net / ORCID iD: https://orcid.org/0000-0002-9671-5953 


\section{INTRODUCCIÓN}

La figura de Pablo de Olavide y Jáuregui se encuentra entre los ilustrados de mayor renombre que se hicieron presentes en las instituciones de gobierno de la España de Carlos III. ${ }^{3}$ Su talento y capacidad facilitaron que, en su Lima natal, finalizase sus estudios con una precocidad sorprendente; pasando muy pronto a desempeñar cargos académicos y a ocupar una plaza de oidor en la Audiencia y Cancillería Real de la capital del virreinato del Perú cuando aún no había cumplido la mayoría de edad. No obstante, también desde muy temprano dio muestras de la fuerte influencia que las ideas ilustradas tenían en sus palabras y acciones, con lo que los problemas y conflictos no tardaron en hacerse presentes; sobre todo cuando se le encomendaron las labores de reconstrucción de Lima tras el terremoto de 1746. Una realidad con la que tuvo que lidiar durante casi toda su vida, pues su carácter impulsivo le impediría medir adecuadamente el alcance de sus comentarios y de sus decisiones, no dudando, siempre que pudo, en tratar de hacer cambios en su entorno acordes con sus ideas, aunque ese entorno no mostrara interés en ellos.

No es extraño, pues, que los sectores más reaccionarios, tanto de la administración como de la Iglesia, viesen un verdadero desafío en sus iniciativas e ideas; especialmente porque sintonizaban bien con las de otros ilustrados de la Corte, como Pedro Rodríguez de Campomanes, el conde de Aranda o Miguel de Múzquiz. Unos contactos y amistades que le facilitaron la posibilidad de ser designado para ocuparse de la puesta en marcha y gobierno de las Nuevas Poblaciones que se establecieron, a partir de 1767, en distintos espacios despoblados de la Sierra Morena giennense, de la provincia de La Mancha y en las proximidades del camino real entre Córdoba y Carmona. El grueso de los pobladores serían los seis mil colonos centroeuropeos que traería a España el coronel bávaro Johann Kaspar von Thürriegel en virtud de la contrata que firmó con la Corona española en abril de ese mismo año, ${ }^{4}$ a los que pronto se sumarían casi medio millar contratados con el suizo Josef Anton Jauch ${ }^{5}$ y un buen número de españoles de distintos puntos de la península ibérica.

Como superintendente de estas Nuevas Poblaciones de Sierra Morena y Andalucía gozó de una serie de competencias y prerrogativas que le permitieron hacer realidad su deseo de poner fin en ellas a diferentes costumbres españolas que consideraba atrasadas y perjudiciales; un poder reforzado, aún más si cabe, por los otros dos cargos que también se le confirieron con vistas a evitar conflictos que

3 Abreviaturas utilizadas: AGS=Archivo General de Simancas (Valladolid); $\mathrm{AHN}=$ Archivo Histórico Nacional (Madrid); $\mathrm{AHPCO}=\mathrm{Archivo}$ Histórico Provincial de Córdoba; APLC=Archivo Parroquial de La Carlota; BCLM=Biblioteca de Castilla-La Mancha (Toledo). Los trabajos que se han ocupado de su trayectoria biográfica y principales realizaciones son muy abundantes, aunque siguen siendo imprescindibles sus dos mejores biografías: Defourneaux 1965 y Perdices de Blas 1992. En lo que respecta a su proceso inquisitorial y conflictos de poder en la corte, resulta esencial Gómez Urdáñez 2015.

4 Disponemos de varias investigaciones sobre la figura de Thürriegel (Weiss 1907, Fílter García 2018 y Hamer Flores 2010), mientras que una transcripción del texto de la contrata de 2 de abril de 1767 está incluida en Hamer Flores 2018, 21-32.

5 Acerca de Jauch y sus colonos suizos véanse: Bolzern 1988 y 1991 y Hamer Flores 2009b, 48-52. impidiesen el éxito de esas nuevas colonias: la Asistencia de Sevilla y la Intendencia de Ejército de los cuatro reinos de Andalucía. ${ }^{6}$ Sin organismos colegiados en esa jurisdicción que pudieran servir de contrapoder y debiendo responder solo ante el Consejo de Castilla y la secretaría de Estado y del Despacho de Hacienda, nuestro personaje encontró un escenario inmejorable para llevar sus ideas a la práctica.

Sin embargo, como decíamos, la prudencia nunca fue uno de los rasgos más destacados de la personalidad de Olavide. Su impulsividad lo llevó a mantener frecuentes disputas y a dar una imagen de persona irreflexiva y de opiniones volubles. Buena prueba de ello es el testimonio del ingeniero militar Carlos Lemaur, encargado de las obras del paso de Despeñaperros y con el que el limeño tuvo trato en múltiples ocasiones durante años, el cual nos dice de él que era «un hombre que habla[ba] de todas cosas sin mucha reflexión, y con poco conocimiento, ya las materias sean filosóficas ya sean de religión, pues las más de las veces caía en contradicción consigo mismo». ${ }^{7}$ Una actitud que proporcionó poco a poco al Tribunal del Santo Oficio testimonios suficientes como para dictar en 1778 una sentencia condenatoria en la que fue calificado, entre otros, como hereje formal y miembro podrido de la religión. Esas delaciones y declaraciones realizadas ante la Inquisición, dado que muchos de los testigos estaban directa o indirectamente vinculados con las Nuevas Poblaciones, nos aportan datos muy interesantes acerca de las medidas relacionadas con el modelo de religiosidad que el superintendente trató de implantar en una nueva sociedad caracterizada por la presencia mayoritaria de labradores con explotaciones familiares de mediano tamaño y que vivían en un entorno donde muchos elementos que se consideraban perjudiciales, como las órdenes regulares, la compraventa y herencia de cargos públicos o la amortización de la propiedad estaban prohibidos.

Algunas de estas informaciones han sido fuente fundamental en estudios de carácter general sobre Olavide, sobre todo los de Marcelin Defourneaux (1965) y Luis Perdices de Blas (1992); aunque en todos ellos se constata la tendencia a centrar el discurso en las iniciativas y sucesos desarrollados en la ciudad de Sevilla, dejando en un segundo plano lo ocurrido en otros espacios. Ello explica que, hasta la fecha, esta importante fuente documental no haya sido analizada para localizar las pruebas que evidenciasen la plasmación, por parte del superintendente, de un pensamiento diferente en un lugar concreto, las nuevas colonias, aprovechando que los beneficiarios de los cambios serían labradores y artesanos y no la población que residía en una de las mayores ciudades del sur peninsular. Es por ello por lo que el objetivo principal de esta investigación consistirá en realizar una aproximación al modelo de religiosidad que Pablo de Olavide trató de establecer entre los colonos de las Nuevas Poblaciones de Sierra Morena y Andalucía en sus primeros años de existencia valiéndose de las amplias competencias

6 Gazeta de Madrid no 25, martes 23 de junio de 1767, 201. El 23 de junio de 1767, el rey «ha nombrado a D. Pablo de Olavide para que le suceda [a Ramón de Larumbe] en la Intendencia y Asistencia [de Sevilla] en atención a su celo y constante aplicación por el servicio del rey y bien del público, confiriéndole también la Superintendencia de las Nuevas Poblaciones proyectadas en Sierra Morena».

7 AHN, Inquisición, leg. 1866, pieza 3, testigo 139 (Carlos Lemaur, 
que le concedía su cargo de superintendente. ${ }^{8}$ Emplearemos para este fin, sobre todo, las ya mencionadas declaraciones de testigos, en un número superior al centenar y medio, que la Inquisición recopiló durante la instrucción de su proceso inquisitorial. ${ }^{9}$ En ellas se plasmaron algunos datos relacionados con el asunto que aquí nos ocupa, fundamentalmente sirviendo de contexto cuando se exponen otras cuestiones, circunstancia que explica su elevada dispersión y que, por lo general, no ofrezcan tantos detalles como nos gustaría. En cambio, el hecho de no constituir, en muchas ocasiones, el objetivo principal de la respuesta que se les pedía, garantiza un mayor grado de objetividad en lo narrado. En cualquier caso, no hemos renunciado a integrar también en nuestra investigación todos aquellos testimonios documentales y referencias bibliográficas que permiten completar, ampliar y entender todo lo que dichos testimonios aportan.

Al igual que ocurriera en Lima, Madrid o Sevilla, las decisiones adoptadas por el superintendente en sus años al frente de las nuevas colonias no tardaron en generar fricciones con las autoridades eclesiásticas e incluso con los propios colonos, los cuales no compartieron de manera generalizada ni las formas ni el fondo de lo que se les ofrecía. De ahí que también consideremos de enorme interés el estudiar esas resistencias que mostraron al ejercicio del poder. El «todo para el pueblo, pero sin el pueblo», tan característico de este siglo de Despotismo e llustración, que el limeño empleó para esas reformas constituyó uno de los principales inconvenientes para el éxito y viabilidad de aquello que consideraba beneficioso para una sociedad mejor. Sus deseos se frustraron en 1776, pero nos queda esta interesante, a la par que breve, iniciativa reformista que estuvo en vigor durante varios años en una pequeña provincia de nuestro país.

\section{Las nuevas Poblaciones de Sierra Morena y Andalucía: UNA SOCIEDAD AGRARIA MODELO EN LA ESPAÑA DE CARLOS III}

Las conocidas como Nuevas Poblaciones de Sierra Morena y Andalucía nacieron a partir de 1767 como una jurisdicción independiente que tuvo como ley suprema el Fuero de población de 5 de julio de $1767 .{ }^{10}$ En un proceso gradual que se extendió desde esa fecha hasta 1776 se le irían agregando una serie de territorios hasta formar dos grandes partidos territoriales: las Nuevas Poblaciones de Sierra Morena, con capital en La Carolina, y las Nuevas Poblaciones de An-

8 Estas atribuciones, derivadas de una férrea defensa del regalismo entre los ministros ilustrados de Carlos III, alimentaron en parte del clero de las nuevas colonias un fuerte rechazo hacia las iniciativas y decisiones de Pablo de Olavide. Del mismo modo, tampoco fue fácil a nivel estatal esa dialéctica entre Estado e Iglesia (Caro López 2004).

9 La mayor parte de la documentación acumulada durante la instrucción de su causa se encuentra actualmente incluida en un voluminoso legajo de la sección Consejo de Inquisición del AHN. Dado que este se distribuye en diez piezas de considerable grosor y que contiene declaraciones y documentos fechados entre 1766 y 1781, hemos optado en el presente trabajo por ofrecer al lector unas referencias concretas (pieza del legajo, número y nombre del testigo y año en el que realizó la declaración) que faciliten la localización del testimonio citado y, a la vez, permitan identificar siempre el origen de la información.

10 Para profundizar en la historia de estas nuevas colonias es imprescindible la consulta de Alcázar Molina 1930, Sánchez-Batalla Martínez 1998-2003 y Hamer Flores 2009a. En relación al Fuero en sí, véase Delgado Barrado 2018. dalucía, con capital en La Carlota. ${ }^{11}$ Una división que se trasladó también al plano gubernativo y de administración. Así, la Intendencia de las Nuevas Poblaciones de Sierra Morena y Andalucía se dividía en dos subdelegaciones, ${ }^{12}$ las cuales se correspondían con los mencionados partidos territoriales y tuvieron al frente a subdelegados bajo las órdenes del intendente; a su vez, cada subdelegación estuvo integrada por varias feligresías o colonias que fueron gobernadas, habitualmente, por un comandante civil. En lo que respecta a la administración, la autonomía de ambas subdelegaciones fue muy amplia, tanto que en materia hacendística cada una dispuso de su propia Contaduría y se rendían cuentas por separado al gobierno.

Los motivos que llevaron a impulsar esta colonización agrícola, más allá del coyuntural derivado de la propuesta realizada en 1766 por Thürriegel, han sido un tema recurrente en la historiografía neopoblacional hasta haber consensuado, a grandes rasgos, un total de cuatro objetivos fundamentales. En primer lugar, se aspiraba a poner en cultivo tierras hasta entonces baldías o poco aprovechadas, con lo que eso también implicaría de desarrollo para otros sectores asociados a cualquier núcleo poblacional, aumentando la riqueza del país. En segundo lugar, se pretendía aumentar la población útil con la entrada en los territorios de la Corona española de varios miles de labradores y artesanos extranjeros que se establecerían y generarían riqueza en esas tierras baldías. La protección de la principal vía de comunicación de la Península, la que unía Madrid con Cádiz y, por tanto, con los territorios americanos, constituyó el tercer gran objetivo de este proyecto colonizador. La apuesta por ese camino real a partir de 1761 evidenció que existían grandes extensiones en las que apenas podían verse algunas pequeñas ventas, por lo que se procuró prestarle protección y dotarlo de mejores servicios en esos tramos con la construcción de nuevos pueblos. Finalmente, el cuarto y último objetivo, muy ambicioso y compartido de facto solo por un reducido círculo de ilustrados, consistió en ensayar en esta colonización un modelo de sociedad agraria en la que no estuvieran presentes ciertos elementos del Antiguo Régimen que eran vistos entonces como un freno para el desarrollo del Estado y que, por tanto, pudiera servir de referencia para aplicarse en otros lugares ${ }^{13}$.

11 Las Nuevas Poblaciones de Sierra Morena estuvieron integradas por los territorios de los actuales municipios jiennenses de Aldeaquemada, Santa Elena, La Carolina, Carboneros, Guarromán, Arquillos y Montizón; por su parte, las de Andalucía se conformaron con los de los municipios cordobeses de La Carlota, Fuente Palmera, Fuente Carreteros y San Sebastián de los Ballesteros y los sevillanos de La Luisiana y Cañada Rosal. Además, entre 1776 y 1799, una enorme extensión del término de Hornachuelos (Córdoba) también se integró en las Nuevas Poblaciones de Andalucía, siendo conocido como Sierra del Tardón.

12 Las nuevas colonias nacieron en 1767 como una Superintendencia, pero en 1784 se modificó su estructura de gobierno: la Superintendencia pasó a ser una Intendencia y aunque continuaban existiendo dos subdelegaciones, se optó por nombrar subdelegado solo en las Nuevas Poblaciones de Andalucía; en las de Sierra Morena el contador asumiría las funciones de subdelegado, lo que permitía que pudiera realizar las comisiones y trabajos que el intendente le encomendase y que lo sustituyese en sus ausencias y enfermedades. En las colonias de Andalucía, el contador podía ejercer esas mismas funciones cuando fuera necesario.

13 La tarea de redactar el Fuero de 5 de julio de 1767 se encomendó a Pedro Rodríguez de Campomanes, fiscal del Consejo de Cas- 
Es por ello que el fuero de 1767 contendría medidas tan significativas como prohibir la acumulación, división y, sobre todo, la amortización de las propiedades, con lo que se garantizaría siempre que estas pudieran mantener con sus frutos una unidad familiar; impedir que los empleos y cargos de gobierno pudieran heredarse o enajenarse; establecer la instrucción primaria como obligatoria; o no permitir el establecimiento de comunidades religiosas regulares dentro de esta jurisdicción, así como tampoco las actividades de esos clérigos. Un punto, este último, de extraordinaria importancia para nuestra investigación, de ahí que ofrezcamos a continuación una breve panorámica de la visión ilustrada sobre el clero y de cómo se plasmó en las Nuevas Poblaciones de Sierra Morena y Andalucía.

Las autoridades españolas esperaban que el clero actuara como un agente activo del reformismo borbónico, sobre todo en el ámbito rural, decantándose para ello y sin disimulo por los curas parroquiales, a los que consideraban mucho más preparados que al clero regular. No fue fácil pero la aplicación de una política regalista enfocada a conseguir la constitución de una Iglesia independiente de Roma y la primacía del orden temporal contribuyó significativamente a este objetivo (Atienza López 2012). Las nuevas colonias de Sierra Morena y Andalucía ejemplifican muy bien esta idea pues, durante las últimas décadas del siglo XVIII, el regalismo fue tan marcado en ellas que el rey debía autorizar todos los nombramientos de eclesiásticos y, además, se ocupaba de abonarles sus salarios e incluso de sufragar casi todos los gastos de culto. ${ }^{14}$ Esos curas serían los únicos en los que recaerían las materias de índole espiritual, logrando así, en teoría, un clero con menor margen para combatir la acción reformadora de la monarquía dado que su permanencia en el cargo y sus rentas dependían directamente del rey (artículos 18 y 20).

Como decíamos, los reformistas veían a los frailes, tan apreciados por las capas populares, como una carga para las poblaciones. Su mantenimiento, en un contexto de excesivo número de conventos y religiosos, los obligaba a salir para pedir limosnas por ser insuficientes sus rentas. Unas salidas que facilitaban el relajamiento en sus costumbres, sus presiones sobre la sociedad y el incumplimiento de sus reglas. Además, aunque las órdenes mendicantes estaban cerca del pueblo y teóricamente conocían bien sus problemas, los ilustrados consideraban que este clero mantenía predicaciones supersticiosas y fanatizadas, contribuyendo a mantener la ignorancia cultural y teológica. No puede extrañar, pues, que los gobiernos borbónicos promovieran medidas que afectaron a la estructura interna de la clerecía; algunas tan llamativas como las resoluciones del Consejo de Castilla a partir de 1762, conducentes a impedir que las casas religiosas pudieran admitir a más miembros de los que podían mantener con sus rentas (Fernández Díaz 2004, 359-363; Barrio Gozalo 2000, 93-102; Rey Castelao 1992, 130-134), o la que se detalló en el artículo 77 del fuero de población prohibiendo absolutamente la fundación de conventos en las nuevas colonias de Sierra Morena y Andalucía.

tilla. En este corpus legal, al igual que en otros de sus trabajos, dejó patente su interés por la puesta en marcha de una reforma agraria en nuestro país. Véase Perrupato 2018.

14 La cuestión del regalismo en España ha generado una abundante bibliografía, entre la que destacamos algunos trabajos de Egido López 1991 y 2003; Hera Pérez-Cuesta 2014; y Mestre Sanchís 1991 y 2004.
En cualquier caso, la creación de un contexto ideal para desarrollar el reformismo borbónico en la jurisdicción que aquí analizamos no constituyó una garantía de éxito. Las ideas y reformas que su primer superintendente puso en marcha, o trató de impulsar, no tuvieron en cuenta la prudencia y los tiempos necesarios en asuntos de religión; de ahí que Pablo de Olavide se granjease no solo la enemistad de la mayor parte del clero empleado en esas colonias sino además el recelo de algunos sectores populares que no compartían el modelo de religiosidad que se intentaba que asumiesen y, menos aún, algunos de los procedimientos coercitivos aplicados con este fin.

\section{EL MODELO DE IGLESIA Y RELIGIOSIDAD DE PABLO DE OLAVIDE APLICADO EN LAS NUEVAS COLONIAS}

El clero tuvo una enorme influencia en los valores que debían guiar el comportamiento social de los españoles durante el siglo XVIII. En su alianza con la nobleza, contribuyó a articular una cosmovisión nobiliario-cristiana desde la que se difundió un modelo de organización justa y correcta de la sociedad. La Iglesia, a través del púlpito y de la educación, transmitía todos esos valores sociales; valiéndose solo de mecanismos represivos, como la excomunión o la acción de la Inquisición, cuando estos recursos fallaban. Los medios más usuales y eficaces se apoyaron en los sermones dominicales, en los confesionarios y en las predicaciones populares en calles y plazas, haciendo que la doctrina católica impregnase el conjunto de la vida española aún a pesar de que la preparación doctrinal de la mayor parte de la población estaba bajo mínimos.

La desafección a las prácticas religiosas, por tanto, siempre mostró enorme timidez. La población seguía ampliamente costumbres como la misa, el rezo o el cumplimiento de los sacramentos. Espacios en los que el control de la clerecía era casi total, pues la Corona y las máximas dignidades del país se tomaron siempre muy en serio todas estas demostraciones de fe. Del mismo modo, otras actividades religiosas gozaron durante esta centuria de una generalizada y fervorosa acogida. Por ejemplo, en la ciudad de Cádiz el rezo del rosario se hacía tres veces al día y en la de Sevilla, donde tenía lugar por las calles, se celebraba más de ochenta veces al año. Los actos litúrgicos anuales, contabilizados por decenas y que marcaban el calendario, disfrutaban de una participación mayoritaria; al igual que las procesiones y rogativas, donde se visualizaba con claridad el orden social del Antiguo Régimen y el papel de la Iglesia como entidad divina en el mundo temporal. Así mismo, otra prueba del nivel de sacralización de la sociedad lo constituían las cofradías, eficaces organismos intermediarios entre la Iglesia y la sociedad, las cuales, a pesar de algunos intentos por limitarlas, no dejaron de crecer en número y feligreses en el Siglo de las Luces (Fernández Díaz 2004, 333-340).

Los intentos reformistas orientados a controlar la religiosidad popular se enfrentaron, pues, con una estructura tremendamente sólida y en la que apenas se dejaron sentir algunas medidas orientadas a profundizar en el regalismo. ${ }^{15}$

15 Este fue el caso, por ejemplo, del establecimiento de la supremacía de la censura real sobre la censura inquisitorial en 1768 , lo que permitió una mayor y mejor difusión de las ideas ilustradas (Cañas Mu- 
Un ambiente tan sacralizado hacía poco prudente para el movimiento ilustrado la adopción de medidas que fueran más allá de perseguir comportamientos que se desviaban de la ortodoxia católica en las celebraciones religiosas o que no contaran con la colaboración de algunos obispos para introducir cambios en la ordenación de sus diócesis (Martínez Shaw 1996, 66-70), lo cual no impidió alguna destacada excepción como la que aquí estudiaremos. Entre 1767 y 1776, el limeño Pablo de Olavide impulsó en las Nuevas Poblaciones de Sierra Morena y Andalucía un conjunto de medidas que no solo afectaron a la religiosidad popular de sus habitantes, sino que incluso interfirieron en las propias actividades litúrgicas del clero.

El escaso apego que nuestro personaje sintió por muchas de las prácticas y celebraciones del catolicismo de su época, a las que consideraba reflejo de supersticiones y mecanismos de obtención de beneficios económicos, tuvo una de sus plasmaciones prácticas más claras en la colonización que aquí estudiamos. Su creación ex novo y los amplios poderes que le confería su cargo de superintendente facilitaron que pudiera aplicar en ellas una serie de medidas novedosas que, como era de esperar, contaron pronto con numerosos detractores y con la propia resistencia de un sector de la sociedad poco dispuesto a que se alterasen sus costumbres y prácticas religiosas. Todavía en febrero de 1782 , seis años después de la marcha del superintendente, el misionero capuchino fray Diego José de Cádiz tuvo ocasión de darse "por entendido contra los errores de su poblador Olavide» en los seis sermones que pronunció en La Carolina a sus vecinos y eclesiásticos, por lo que les exhortó «a detestar los errores en la fe y costumbres que él les había inspirado» (Valenciana 1924, 571).

Los ámbitos en los que más destacó esta influencia de Olavide pueden concretarse en cuatro: el diseño de los lugares de culto y su dotación, la creación de altares, la celebración de los oficios religiosos y las expresiones de fe en los espacios públicos. Los próximos apartados, dada su trascendencia, los destinaremos a ofrecer detalles sobre cada una de estas cuestiones.

\section{Los lugares de culto: iglesias y capillas}

En los años que dirigió las nuevas colonias, el individuo que aquí estudiamos destacó por su deseo de limitar el número de altares en los templos y por centrar el culto en la Inmaculada Concepción y en el propio Dios. En virtud de las competencias que le confería el Fuero, se ocupó no solo de dotar estas nuevas poblaciones de edificios de carácter civil sino también de aquellos necesarios para el culto religioso, construyéndolos de nueva fábrica o adaptando los preexistentes. En lo referido a los templos ya existentes en 1767, podemos indicar que en los terrenos que fueron utilizados para fundar las colonias de Sierra Morena se encontraban un convento, seis ermitas y una capilla (Pérez Fernández 2019b, 201-212), mientras que en las de Andalucía encon-

rillo 2004). En cualquier caso, ese impulso de las impresiones durante el reinado de Carlos III no redujo el control civil sobre las ideas al mantener el Consejo de Castilla un férreo control sobre el nombramiento de los censores que darían o no su visto bueno a las solicitudes de impresión que llegaban a la sala de gobierno (Castro 1996, 251-256). tramos una capilla en San Sebastián de los Ballesteros y, posiblemente, otra en La Carlota.

Las costumbres religiosas de los lugares colonizados, así como algunas de las devociones ya existentes en ellos, ${ }^{16}$ influyeron en los nuevos pobladores pese al control y medidas impulsadas por el superintendente. Aunque los colonos establecidos procedían en su mayor parte de regiones muy lejanas, esos cultos preexistentes tuvieron en ellos una enorme fuerza, siendo asimilados con rapidez y, con el paso de los años, acabaron imponiéndose casi por completo a las propuestas defendidas por Olavide. ${ }^{17}$

\section{CUADRO 1}

\section{Edificios religiosos preexistentes en la jurisdicción las Nuevas Poblaciones}

\begin{tabular}{|c|c|c|c|c|}
\hline Partido & Colonia & Tipología & № & Advocación / Orden \\
\hline \multirow{7}{*}{$\begin{array}{l}\text { Sierra } \\
\text { Morena }\end{array}$} & \multirow[b]{2}{*}{ La Carolina } & Convento & 1 & Carmelita (con capilla) \\
\hline & & Ermita & 2 & $\begin{array}{l}\text { San Juan de la Cruz } \\
\text { / Nuestra Señora del } \\
\text { Carmen }\end{array}$ \\
\hline & $\begin{array}{l}\text { Santa } \\
\text { Elena }\end{array}$ & Ermita & 1 & Santa Elena \\
\hline & El Rumblar & Ermita & 1 & $\begin{array}{l}\text { Nuestra Señora de } \\
\text { Zocueca }\end{array}$ \\
\hline & $\begin{array}{l}\text { Miranda } \\
\text { del Rey }\end{array}$ & Ermita & 1 & $\begin{array}{l}\text { Nuestra Señora de la } \\
\text { Encina }\end{array}$ \\
\hline & Arquillos & Capilla & 1 & San Antonio Abad \\
\hline & $\begin{array}{l}\text { Venta de } \\
\text { los Santos }\end{array}$ & Ermita & 1 & $\begin{array}{l}\text { Nuestra Señora de } \\
\text { Nazaret }\end{array}$ \\
\hline & La Carlota & Capilla & 1 & $\begin{array}{l}\text { Nuestra Señora de los } \\
\text { Ángeles }{ }^{18}\end{array}$ \\
\hline Andalucía & $\begin{array}{l}\text { San Sebas- } \\
\text { tián de los } \\
\text { Ballesteros }\end{array}$ & Capilla & 1 & San Sebastián \\
\hline
\end{tabular}

Fuente: Elaboración de los autores.

16 Para el conocimiento de estos cultos ha sido fundamental la información contenida en: BCLM, ms. 9.

17 En el caso de los colonos españoles, este fenómeno resultaría más fácil debido a que compartían unas prácticas religiosas similares, pero los centroeuropeos, aunque a priori deberían haber sido más reticentes, también participaron pronto de esas mismas prácticas; un ejemplo significativo de ello fue el impulso del culto a San Juan de la Cruz en La Carolina por parte de los frailes capuchinos alemanes y los colonos de dicha procedencia

18 Las referencias a esta capilla son muy vagas en la documentación, pues solo se indica su advocación en un documento (APLC, Libro 10 de Matrimonios), pero consideramos que es muy probable que se trate del pequeño recinto destinado al culto que se situaba junto a la venta de La Parrilla o del Arrecife, incluida dentro de la jurisdicción de La Carlota a partir de 1768. A mediados del siglo XVIII, según el catastro de Ensenada, la referida venta se describía como una "habitación baja y alta, sacristía y capilla para celebrar misa con diez y seis varas de frente y veinte de fondo" (AHPCO, Hacienda, Catastro de Ensenada, libro 560, f. 431r). Frente a esta posibilidad, también debe considerarse la existencia de otro recinto para el culto próximo a los límites jurisdiccionales de esta colonia, situado actualmente dentro del municipio de La Victoria, consistente en un oratorio que el convento cordobés de Nuestra Señora de la Victoria poseía en el pago de La Guijarrosa, dentro del municipio de La Rambla (AHPCO, Hacienda, Catastro de Ensenada, libro 557, f. 428v). Aun así, esta última opción parece improbable pues todo apunta a que ese oratorio siempre estuvo bajo la advocación de Nuestra Señora de La Victoria, hasta tal punto de haber dado nombre al municipio donde se encuentra enclavado. 
Todo ello nos permite trazar dos realidades distintas en los inicios del proyecto de colonización. Por un lado, las colonias donde no existía ninguna fundación religiosa previa (Guarromán, Navas de Tolosa, Carboneros, Aldeaquemada, Montizón, Fuente Palmera y la Luisiana) y, por otro, aquellas donde existía un convento, una capilla o una ermita que pudieron favorecer el mantenimiento de un culto preexistente (La Carolina, Santa Elena, Miranda de Rey, El Rumblar, Arquillos, Venta de los Santos, La Carlota y San Sebastián de los Ballesteros). En las primeras se procedió a erigir nuevos templos en los que se evitó el lujo y únicamente se crearon las capillas y altares imprescindibles, destinados al Santísimo Sacramento y a la Inmaculada Concepción. Por su parte, en las segundas las intervenciones y el devenir fueron algo más complejos. Siempre que su ubicación lo facilitara, los antiguos templos fueron adaptados para servir como nuevas iglesias de las colonias que se fundaron; caso, por ejemplo, de La Carolina, de Santa Elena o de Arquillos. Cuando ello no fue posible, también se levantarían edificios de nueva fábrica para que sirvieran como iglesias o capillas. Ni que decir tiene que, aunque se mantuvieron algunos de los cultos precoloniales, en todas ellas se impulsaría la devoción a la Inmaculada y se vigiló que no aumentaran los altares dedicados a santos.

\section{Las imágenes y los altares}

Aunque Pablo de Olavide pretendió y logró, como ya hemos indicado, que en las iglesias hubiera el menor número de altares posible y que estas se colocasen bajo la advocación y patronazgo de la Inmaculada Concepción (Espinalt García 1787, 94), lo cierto es que en aquellos casos en los que los templos reaprovecharon iglesias o capillas previas, situados casi todos en las colonias de Sierra Morena, no pudo cumplirse estrictamente este deseo como vimos con anterioridad. Nos da buena cuenta de ello el capellán mayor Juan Lanes y Duval al afirmar que, aunque en algunas colonias se disponía solo de un altar mayor, no en todas estaba ocupado por la Inmaculada Concepción ni era el único. La parroquia de La Carolina se dedicó a la Purísima y a San Carlos Borromeo, con dedicación expresa a la onomástica del monarca, y la de El Rumblar parece ser que continuó bajo la advocación de Nuestra Señora de Zocueca. ${ }^{19}$

Como es lógico y estamos comprobando, los templos preexistentes poseían imágenes que el superintendente encontró a su llegada, las cuales, aunque no se vieron incrementadas con ninguna otra en los años siguientes, permanecieron dentro de ellos. En los altares de Arquillos, Venta de los Santos (anejo de la parroquia de Montizón) y Miranda del Rey estaban colocadas las imágenes de San Antonio Abad, Nuestra Señora de Nazaret y Nuestra Señora de la Encina, respectivamente. Además, en el santuario de El Rumblar la Virgen de Zocueca ocupaba el altar mayor y se disponía de altares laterales donde podía verse también a San Francisco y a San Antonio. ${ }^{20}$ No obstante, el principal problema ante el que se encontró Olavide no estuvo en la existencia de esas imágenes sino en el hecho de que dos

\footnotetext{
19 BCLM, ms. 9, p. 108.

$20 \mathrm{AHN}$, Inquisición, leg. 1866, pieza 3, testigo 141 (Juan Lanes y Duval, 1777).
}

de ellas (Nuestra Señora de Nazaret y la Virgen de Zocueca) recibieran un enorme culto por recaer en ellas el patronazgo de localidades vecinas. Los conflictos con los devotos de Chiclana y Bailén no se hicieron esperar. De este modo, aunque la Virgen de Zocueca pudo permanecer en su templo durante los primeros años de la colonización, en el caso de Nuestra Señora de Nazaret, las tensiones solo se resolvieron en 1774 cuando los vecinos de Chiclana se la llevaron en rogativa. Los colonos de Venta de los Santos repararon entonces la iglesia, trasladando al Cristo de la Expiración desde la sacristía al altar mayor en torno a 1780, dedicando las fiestas locales al Cristo y adquiriendo una nueva imagen de la Virgen (Pérez Fernández 2019b, 203-204).

La capilla del convento carmelita de La Peñuela se convertiría en la primera iglesia de La Carolina una vez bendecida por el capellán mayor el 2 de abril de $1768 .{ }^{21}$ Heredadas del convento tenemos constancia de la existencia de cinco imágenes que, junto con los ornamentos y vasos sagrados, continuaron formando parte de la dotación de dicha iglesia (Palacios Alcalde 1988, 193). En la misma feligresía, la ermita de San Juan de la Cruz tenía expuesto al culto un cuadro de dicho santo y la ermita de Nuestra Señora del Carmen, un busto de dicha advocación. ${ }^{22}$ La ermita de Santa Elena estaba dotada con imágenes de Santa Elena, la Inmaculada, San Miguel Arcángel y un cuadro sobre el triunfo de la Santa Cruz en la batalla de las Navas de Tolosa ${ }^{23}$ y la capilla de San Sebastián de los Ballesteros con un lienzo de dicho santo. Podemos comprobar, por tanto, que se pudo disponer desde el primer momento de imágenes de culto para algunas de las feligresías, si bien no parece que se tuviera especial interés por favorecer esas devociones mientras Olavide permaneció en el gobierno.

En las parroquias que se fueron construyendo en cada una de las nuevas colonias, la Superintendencia no mostró mucha prisa en dotarlas con imágenes, mobiliario y vestimentas litúrgicas. Acuciada por otros problemas relacionados con el éxito del proyecto colonizador, como la puesta en cultivo de las tierras, esta se limitó a distribuir los bienes procedentes de los colegios de la Compañía de Jesús que el rey había destinado para ellas, evitando en la medida de lo posible que los altares alojaran otras tallas que no fueran las de la Inmaculada Concepción. De este modo, mientras estas se colocaban, en los altares, normalmente únicos, de esos templos solo era posible ver un crucifijo y candeleros; sumándose pronto en algunas de ellas (Navas de Tolosa, Montizón y Carboneros), dadas las dificultades de disponer con rapidez de suficientes imágenes de bulto redondo, cuadros en los que se representaba la Inmaculada. Como cabía esperar, la primera talla disponible se destinó a la capital de las colonias de Sierra Morena, quedando instalada en su camarín el 14 de agosto de $1772 .{ }^{24}$ En cualquier caso, el reaprovechamiento de los retablos jesuitas hizo que también estuvieran presentes en algunas iglesias de nueva fábrica (La Luisiana, Fuente Palmera y San Sebastián de los Ballesteros) varias representaciones de santos, de lo que daba buena cuenta Olavide en una carta fechada en 1776 y dirigida al inquisidor general, Felipe Beltrán, cuando ya el

\footnotetext{
21 BCLM, ms. 9, p. 76.

22 Ibídem, 78 y $85-86$.

23 Ibídem, 91-92.

24 Ibídem, 83, 89, 106 y 107.
} 
limeño estaba preocupado por las acusaciones de sus enemigos y trató de demostrar, sin mucho éxito, que no había impedido el culto a los santos. ${ }^{25}$

Los intentos de defensa del superintendente chocan con la realidad de que, aunque pudiera haber santos en esos retablos, durante sus ocho años de gobierno nunca facilitó que se dedicaran nuevos altares exclusivamente para aquellos. Tanto es así que solo nos consta un intento que nunca llegó a materializarse. Parece que el superintendente acabó cediendo a las peticiones de Lanes y Duval de erigir altares colaterales en la iglesia de La Carolina para colocar en ellos imágenes de santos. Aun así, aunque pidió a su subdelegado Miguel de Ondeano «las medidas de los dos nichos para mandar hacer en Madrid dos buenas efigies ${ }^{26}$ que se colocasen en ellos con sus altares», todavía en 1777 no había ninguna noticia acerca de su realización. ${ }^{27}$ No puede extrañar, por tanto, que muchos vecinos de La Carolina, con diferencia la colonia más poblada y visitada dada su condición de capital de las colonias de Sierra Morena, tuvieran la sensación de que todas las iglesias de ese partido territorial se asemejaban a la que ellos frecuentaban. Un buen ejemplo lo encontramos en el médico Juan Calvet, que estaba convencido de este hecho. ${ }^{28}$ Situación no muy diferente a la que se daba en las colonias de Andalucía, donde todas las iglesias y capillas también se erigieron siguiendo los criterios e indicaciones de Olavide.

Como ya hemos manifestado, en todos los edificios de nueva planta, o que se finalizaron al iniciarse la colonización, el superintendente se opuso a la existencia de altares dedicados a otros santos ${ }^{29} \mathrm{y}$, en el mejor de los casos, solo autorizaba un segundo altar, como ocurrió en La Carlota, para colocar el Santísimo Sacramento. ${ }^{30}$ Este rechazo a la profusión de altares no dudó en manifestarlo también en la ciudad de Sevilla, donde calificó como «pamplinas» el erigir esos altares y acudir a rezar a ellos al saber que así había actuado el marqués de Torreblanca, alguacil mayor de la ciudad, al mandar erigir uno en honor de Santa Elvira Virgen en la parroquia de Santiago ${ }^{31}$ o cuando no le agradó en su visita al Real Seminario de San Telmo el elevado número de altares y santos que pudo ver, dejando claro a uno de los regidores del concejo sevillano que los santos estaban en el Cielo y era suficiente con el altar mayor. ${ }^{32}$ Es decir, actuó siempre más movido por su particular modo de entender la religión y sus expresiones que por un hipotético deseo de

25 AHN, Inquisición, leg. 3609, s.f. Carta de Pablo de Olavide al Inquisidor General, 19 de marzo de 1776. Citada en Sánchez-Batalla Martínez 2000, 2: 430-443.

26 Olavide llegó a comentar que esas efigies serían de San Pedro y San Pablo (AHN, Inquisición, leg. 3609, s.f. Carta de Pablo de Olavide al Inquisidor General, 19 de marzo de 1776. Citado en Sánchez-Batalla Martínez 2000, 2: 430-443).

27 AGS, Secretaría y Superintendencia de Hacienda, leg. 499, doc. 62. Carta de Juan Lanes y Duval a Miguel de Ondeano, 9 de febrero de 1777 , y carta de Miguel de Ondeano a Juan Lanes y Duval, 15 de febrero de 1777.

${ }_{28}$ AHN, Inquisición, leg. 1866, pieza 3, testigo 102 (Juan Calvet, 1777).

${ }_{29}$ Ibídem, pieza 2, testigo 46 (fray Romualdo de Friburgo, 1775) y testigo 56 (Pedro de Vera, 1775).

30 Ibídem, pieza 1, testigo 26 (José Lázaro Sánchez Rubio, 1769).

31 Ibídem, pieza 2, testigo 69 (Fernando Pintado, marqués de Torreblanca, 1776).

32 Ibídem, pieza 3, testigo 130 (Juan Manuel Vivero, 1777). ahorrar gastos a la Real Hacienda en las nuevas colonias. Tanto es así que, aunque no pudo llevarlo a la práctica, trató de colocar dos retratos pintados del rey Carlos III y su hijo el príncipe de Asturias en sendos marcos ovalados de yeso que ideó bajo las ventanas de la media naranja mientras se finalizaba la iglesia de la capital de Sierra Morena; no obstante, la respuesta desfavorable que recibió del Consejo de Gobernación del Arzobispado de Toledo a la consulta que elevó, indicándole que no se consideraba conveniente su colocación, puso fin a esta idea que no habría tenido un presupuesto precisamente barato. ${ }^{33}$ De este modo, las manifestaciones del patronazgo regio en este y otros templos de las nuevas colonias debió restringirse casi únicamente a la colocación del escudo real en lugares preeminentes (Hamer Flores y Pérez Fernández 2019).

Pero ¿por qué Pablo de Olavide apostó por iglesias con un único altar? La respuesta se la proporcionó él mismo al capellán mayor de las Nuevas Poblaciones de Andalucía en 1769, al indicarle que su criterio para la iglesia de La Carlota, que entonces se estaba construyendo, era que solo dispusiera de uno, imitando a las que había tenido ocasión de visitar en Francia. ${ }^{34}$ Se lograba así una vuelta a los primeros tiempos del cristianismo, cuando la norma del altar único, que respondía a la concepción del altar como símbolo de Cristo, estuvo generalizada. Solo a partir del siglo $\mathrm{V}$, en tiempos del papa Símaco (498-514), esta regla comenzó a ser infringida en Occidente por la profusión de reliquias de santos y el aumento de misas privadas, entre otros (Arocena 2006, 34).

La existencia de un único altar no fue el único elemento que resultó llamativo en los templos de las nuevas colonias. Aunque fueron dotados con elementos procedentes de los regulares expulsos, encargándose la Real Hacienda de proveer todo aquello necesario que no llegara desde los colegios de la Compañía, lo cierto es que se caracterizaron en sus años iniciales por una enorme sobriedad en su contenido. Antonio Capmany, que residió en 1775 en La Carolina, sostenía que en su iglesia solo había una mesa de altar con dos candeleros y una cruz encima. ${ }^{35}$ Situación no muy diferente a la que mostraba en 1769 la iglesia de Guarromán, en la que el capellán Francisco Antonio Henseler, que acompañó durante su visita de inspección al consejero de Castilla Pedro José Pérez Valiente, solo pudo ver un altar con un Crucificado y dos candeleros. ${ }^{36}$ Es más, en aquellos casos en los que algún templo se consideró innecesario, como ocurrió con la ermita de San Juan de la Cruz, próxima al núcleo urbano de La Carolina, la administración neopoblacional relegó a un segundo plano su conservación. Se conseguía así, de paso, reducir las manifestaciones de culto hacia este santo, pues las misas que se oficiaron en ella fueron escasas y para las que había que transportar siempre ornamentos y vestimentas desde la parroquia de La Carolina. ${ }^{37}$

\section{Los oficios religiosos}

La intervención de Olavide no se limitó a decidir acerca del número de altares y dotación de las iglesias de las

33 Ibídem, pieza 3, testigo 141 (Juan Lanes y Duval, 1777).

34 Ibídem, pieza 1, testigo 26 (José Lázaro Sánchez Rubio, 1769).

35 Ibídem, pieza 3, testigo 138 (Antonio Capmany, 1777).

36 Ibídem, pieza 3, testigo 82 (Francisco Antonio Henseler, 1776).

37 Ibídem, pieza 3, testigo 101 (Jerónimo de Guillenea, 1777). 
nuevas colonias, sino que incluso llegó a introducir cambios en la forma en la que se realizaban los oficios religiosos. Concretamente, prestó especial interés a la vestimenta femenina y a fomentar la interrelación entre españoles y extranjeros a través de la introducción de composiciones que se cantaban durante la misa. Unas cuestiones en las que mostró casi tanta firmeza como resistencia encontró en el pueblo a su cumplimiento, por lo que se puede entender fácilmente que, tras la marcha de Olavide, desaparecieran con rapidez y por completo.

En un contexto en el que las mujeres no llevaban la cabeza descubierta para ir a la iglesia, incluso las alemanas siempre portaban una pequeña cofia en el pelo, ${ }^{38}$ la exigencia del superintendente de que la llevasen descubierta, hasta para confesar, despertó un recelo generalizado. El sacerdote Francisco de la Coba decía que mandaba que todas las mujeres fueran peinadas y compuestas a la iglesia con la cabeza descubierta y con poca honestidad en los trajes, «pues no es otro su ánimo que vayan al templo como a la plaza, y a misa como a la comedia». ${ }^{39}$ La vigilancia para que se cumpliera esta disposición era estricta y hasta contundente en todas las nuevas poblaciones, permitiéndose en las de Andalucía, como mucho, el que las mujeres llevasen cabriolé. ${ }^{40}$ Cuando el superintendente se las encontraba con sayas y mantilla las apercibía y las desairaba no quitándose el sombrero, ${ }^{41}$ llegando en más de una ocasión a quitarles él mismo las mantillas ${ }^{42}$ y a dar orden de rasgarlas. ${ }^{43}$ Es más, cuando suponía que vestían basquiña por indicación de sus familiares, como ocurrió con la hermana del referido Francisco de la Coba, no dudaba en tacharlos de ridículos por fomentar esta práctica. ${ }^{44}$ Era habitual, pues, que muchas mujeres pasearan y acudieran a misa con la cabeza descubierta a disgusto, suyo y de sus maridos; ${ }^{45}$ mientras que otras procuraban emplearlas a escondidas, en horarios y contextos que dificultasen que el superintendente lo supiese. ${ }^{46}$

Por otro lado, consciente Olavide de la gran heterogeneidad existente en las nuevas colonias, cuyos colonos no solo estaban separados por una barrera lingüística sino también de costumbres religiosas, decidió componer unas canciones, llamadas también coplas por parte de los nuevos pobladores, con el objetivo de que todos los asistentes a la

38 Esta prenda, tal vez por sus reducidas dimensiones, parece que no fue objeto de quejas por parte del superintendente, más preocupado por las que llevaban las españolas.

39 AHN, Inquisición, leg. 1866, pieza 2, testigo 67 (Francisco de la Coba, 1776).

40 Ibídem, pieza 3, testigo 147 (José Lázaro Sánchez Rubio, 1777). El subdelegado Fernando de Quintanilla, a juicio del capellán mayor de La Carlota, defendió el cumplimiento de esta disposición de Olavide, dentro de su jurisdicción, "con violencia».

${ }^{41}$ Ibídem, pieza 3, testigo 90 (Josefa de León 1777) y testigo 91 (Rafaela de León 1777).

42 Ibídem, pieza 3, testigo 100 (Juan Adam Spies 1777).

43 Uno de estos episodios tuvo lugar en 1775, cuando Olavide, que iba acompañado por Rodolfo de León, se encontró con la mujer e hija del molinero del Renegadero, ambas con mantilla, y el superintendente se la quitó a la mujer intentando después rasgarla, aunque sin conseguirlo. Por ello se la dio a León con orden de que la rasgase, hecho lo cual Olavide la cogió, la hizo un lío y la tiró. La discusión fue tan intensa que a la hija «le dio un accidente» (Ibídem, pieza 3, testigo 127: Rodolfo de León, 1777).

44 Ibídem, pieza 2, testigo 67 (Francisco de la Coba, 1776).

45 Ibídem, pieza 3, testigo 138 (Antonio Capmany, 1777).

46 Ibídem, pieza 3, testigo 138 (Antonio Capmany, 1777). misa las cantasen juntos después de la consagración y los extranjeros se fueran familiarizando con la lengua española. Esta idea la concibió tras tener noticia de que en algunas poblaciones de Sierra Morena los colonos y colonas cantaban en sus idiomas, habiendo él mismo oído cantar a unas colonas que fueron a La Carolina desde Miranda del Rey. ${ }^{47}$ En este caso, el superintendente solo pudo introducirlas en las Nuevas Poblaciones de Sierra Morena, ya que la exigencia del capellán mayor de La Carlota de contar para ello con aprobación previa del obispo de Córdoba impidió que su subdelegado Fernando de Quintanilla lograra su implantación en las Nuevas Poblaciones de Andalucía. ${ }^{48}$ Al objeto de facilitar su uso, las mandó imprimir y las repartió entre los colonos para que se las aprendieran..$^{49}$ Afortunadamente disponemos del texto, aunque no del acompañamiento musical, de dos de esas canciones..$^{50}$

Su contenido era respetuoso con la doctrina cristiana pero esta intromisión de Olavide en la misa no fue bien recibida por todo el sector eclesiástico. Junto a opiniones como la del sacerdote José Tomás Stefani, que afirmaba que le movían a mayor devoción, ${ }^{51}$ encontramos otras más neutrales como la de Pedro de Vera que, aunque las consideraba serias y devotas, sostenía que el superintendente mezclaba durante la misa los ritos de la Iglesia con otros suyos, o directamente de rechazo. Este último fue el caso del sacerdote Francisco de la Coba, a quien esas canciones le habían llevado a tener que interrumpir en alguna ocasión los oficios porque le molestaban en su labor. ${ }^{52}$

En lo que respecta a los momentos exactos en los que se cantaban estas composiciones de Olavide, sabemos que ello tenía lugar tanto después de la consagración como después de la última lectura del Evangelio; aún más, en uno y otro momento, se entonaban canciones diferentes. La introducción de esta novedad en las misas tuvo como consecuencia un incremento considerable en su duración, hasta alcanzar casi dos horas. Un hecho que movió a un malestar generalizado entre la población, que trataba de salir de la iglesia lo antes posible para continuar con sus quehaceres, pero que fue respondido por el superintendente con la orden de mandar cerrar las puertas de la iglesia justo antes de proceder a la consagración y abrirlas solo después de concluidos los últimos cantos, que tenían lugar con todos los asistentes de rodillas tras haber concluido la misa. ${ }^{53}$

En esta misma línea destacamos el testimonio de Lanes y Duval, el cual informaba en 1776 de que los colonos participaban en las celebraciones religiosas cantando piezas en latín y castellano. Las autoridades neopoblacionales se esforzaron por enlazar directamente con la tradición alemana, tanto católica como protestante, de utilizar la legua vernácula en los cantos corales transmitidos oralmente e interpretados al unísono por los propios fieles. El propio capellán mayor nos dice que «con su excelente órgano y la porción de colonos que saben algo de canto llano se hacen

47 Ibídem, pieza 3, testigo 102 (Juan Calvet, 1777).

48 Ibídem, pieza 3, testigo 147 (José Lázaro Sánchez Rubio, 1777).

49 Ibídem, pieza 3, testigo 141 (Juan Lanes y Duval, 1777).

50 AHN, Inquisición, leg. 3609, s.f. Ejemplares impresos. Pueden consultarse en Pérez Fernández 2015, 293-294.

51 AHN, Inquisición, leg. 1866, pieza 3, testigo 150 (José Tomás Stefani, 1776).

52 Ibídem, pieza 2, testigo 67 (Francisco de la Coba, 1776).

53 Ibídem, pieza 3, testigo 138 (Antonio Capmany, 1777). 
aquí [La Carolina] fiestas solemnísimas» (Marín López 2018, 1536-1536). Así pues, todo apunta a su uso como un medio de asimilación de los colonos extranjeros y para fomentar la cohesión social, a la par que también potenciaba el uso del español (Pérez Fernández 2019a, 40 y 2019b, 199).

\section{La religiosidad en el espacio público}

Otra de las preocupaciones del superintendente consistió en tratar de limitar aquellas manifestaciones de carácter religioso que consideraba que no debían tener presencia en el espacio público. Su objetivo nunca fue eliminarlas todas, algo casi imposible en un contexto social marcadamente confesional, pero sí enfrentarse a las que consideraba perjudiciales para la economía familiar de los colonos o simples muestras de superstición que la Iglesia avalaba, no pocas veces, por el beneficio económico o de fidelización de fieles que conllevaban. Entre las primeras destaca sobremanera la práctica de pedir limosna por casas, calles y plazas con destino a misas u otras cuestiones religiosas. Olavide la prohibió, cumpliéndose con rigor esta disposición durante toda su etapa de gobierno. En la instrucción que el superintendente elaboró el 17 de diciembre de 1770 para los alcaldes pedáneos de las colonias indicó con claridad, en el artículo 24, que entre las obligaciones que tenían estos alcaldes pedáneos estaba la de vigilar para que nadie pidiera limosna en los departamentos de su jurisdicción. ${ }^{54}$ Un proceder que estuvo siempre orientado a impedir que los colonos empleasen para este fin un dinero que estimaba mejor invertido en su alimentación o vestido, o incluso para realizar mejoras en sus propiedades. Tan efectivo fue el cumplimiento de esta disposición que, por ejemplo, el médico Juan Calvet afirmaba, en 1777, que nunca había visto pedir limosna en las nuevas colonias. ${ }^{55}$

En lo que respecta a las manifestaciones colectivas de religiosidad popular en el espacio público, hemos de considerar tanto las prédicas religiosas como las procesiones o rogativas. Los sermones y actuación en materia de fe de los religiosos debían circunscribirse al interior de los templos, tanto es así que el superintendente rechazaba el rezo del Rosario por las calles o incluso que los eclesiásticos acompañasen al cortejo fúnebre desde la iglesia hasta el cementerio. Ante la desaprobación de Olavide, la práctica del rezo del Rosario solo sobrevivió durante su gobierno en un formato casi marginal. Se realizaba de madrugada, para evitar que el superintendente lo viera, haciendo que tampoco fuera visto por gran parte de la población, y apenas participaban españoles. ${ }^{56}$ La mayor permisividad hacia los extranjeros, muy probablemente, solo fue un gesto para evitar tensiones innecesarias, pues estarían convencidos de que a medida que esa comunidad se hispanizara podría erradicarse esta práctica. En esta misma línea también hemos de mencionar a los particulares que viajaban evangelizando, pues se impidió que desarrollaran esta actividad en las colonias. Un ejemplo de ello lo tenemos en un episodio ocurrido hacia 1772 o 1773 durante uno de los bailes públicos que se celebraban

54 AGS, Secretaría y Superintendencia de Hacienda, leg. 497, doc. 86.

55 AHN, Inquisición, leg. 1866, pieza 3, testigo 102 (Juan Calvet, 1777).

56 Ibídem, pieza 3, testigo 81 (fray Pedro de Madrid, 1777). los días festivos por la tarde en La Carolina, cuando dos jóvenes manchegos aprovecharon la afluencia de público para explicar la doctrina cristiana siguiendo el método del padre Ripalda, haciendo uno las preguntas y respondiéndolas el otro. Olavide, al ser informado de la presencia de los muchachos, dio orden al alguacil mayor de que los expulsase de la localidad. ${ }^{57}$

Las procesiones y rogativas tampoco contaron con mejor opinión por parte de Olavide. Durante la primera década de existencia de La Carolina, aparte de las procesiones anuales obligatorias, ${ }^{58}$ sus calles solo presenciaron otras dos autorizadas por las instituciones neopoblacionales. No obstante, la segunda de ellas, al haberse realizado sin conocimiento del superintendente, contó con su firme rechazo, pues argumentó en abril de 1775 que estas prácticas eran supersticiosas y solo contribuían a alborotar al pueblo y a encarecer el precio del grano..$^{59}$ En 1773, ante la falta de lluvias, Olavide autorizó e incluso participó, junto a su familia, en una rogativa que se hizo por las calles de La Carolina con la imagen de la Inmaculada Concepción. Durante las letanías los asistentes pedían fervorosamente el agua que tanto necesitaban los trigos, ${ }^{60}$ hasta el punto de que pudieron ver al superintendente incluso derramar lágrimas. No obstante, cuando dos años más tarde los campos requerían con urgencia que lloviese para que no se perdiesen las cosechas, su reacción fue muy diferente. En la primavera de 1775 no residía en La Carolina, de ahí que su subdelegado Miguel de Ondeano fuera el encargado de autorizar una nueva procesión de la Inmaculada Concepción para rogar por las lluvias. Una decisión que solo sometió a consulta en una sociedad que se intentó establecer en la capital de Sierra Morena, ${ }^{61}$ y que contó con su visto bueno. ${ }^{62}$ Pero el superintendente, como ya hemos manifestado, consideró inapropiada y perjudicial esta procesión, reprendiendo tanto por escrito como en persona a su subdelegado por haberla autorizado sin su conocimiento. ${ }^{63}$ Un sentir que no dudó en exteriorizar en la procesión del Corpus Christi de ese mismo año 1775 en La Carolina. En ella, al alcalde mayor de las colonias de Sierra Morena, Luis de Herrera, le tocó situarse al lado derecho de Olavide; aprovechando este para verificar qué había de cierto en los rumores que circulaban de que el superintendente se oponía a todas las procesiones. Herrera le dijo que solo debería hacerse la procesión del Corpus, a lo que Olavide le respondió que ni siquiera esa. ${ }^{64}$

En lo que respecta a los oficios y actos vinculados con la Semana Santa, todo parece indicar que durante los años que estudiamos no se produjo ninguna procesión en las nuevas colonias, circunstancia, sin duda, facilitada por la

57 Ibídem, pieza 3, testigo 144 (Diego Rodajo, 1777).

58 Ibídem, pieza 3, testigo 102 (Juan Calvet, 1777).

59 Ibídem, pieza 3, testigo 141 (Juan Lanes y Duval, 1777).

60 Ibídem, pieza 3, testigo 102 (Juan Calvet, 1777).

61 Esta sociedad, que tuvo el nombre de "La Carolina», parece ser un intento fallido de establecer en las Nuevas Poblaciones de Sierra Morena y Andalucía un organismo similar a las Sociedades Económicas de Amigos del País que por aquel entonces estaban difundiéndose en nuestro país.

62 AHN, Inquisición, leg. 1866, pieza 3, testigo 149 (Luis de Herrera, 1777).

63 Ibídem, pieza 3, testigo 138 (Antonio Capmany, 1777) y testigo 141 (Juan Lanes y Duval, 1777).

64 Ibídem, pieza 3, testigo 149 (Luis de Herrera, 1777). 
inexistencia generalizada en las iglesias de imágenes adecuadas para este propósito. Aún más, todo apunta a que el superintendente ni siquiera consideraba necesario interrumpir sus actividades de ocio y entretenimiento durante todos esos días. En este sentido, disponemos de un interesante testimonio fechado en la Semana Santa del año 1769, que Olavide pasó en La Carlota. Uno de los capataces que trabajó en esa capital en sus primeros años aseguró que fue testigo de cómo el Jueves Santo y el Viernes Santo del año 1769 el superintendente participó durante todo el día en una montería por los montes de esta colonia acompañado por muchas personas, de ahí que no asistiera a los oficios sagrados. $^{65}$

Finalmente, otra cuestión que preocupó a Olavide fue el de la indumentaria y la exhibición de símbolos. Si sentía escasa simpatía por los pañuelos, mantillas y otras prendas con las que las mujeres se cubrían el cuerpo hasta casi solo mostrar el rostro, tanto cuando acudían a la iglesia como cuando transitaban por las calles, el uso de hábitos de las órdenes religiosas le molestaba enormemente. Rechazó abiertamente que los seglares los llevasen como indumentaria y, más aún si cabe, que vistiesen con ellos a sus hijos. ${ }^{66}$ Del mismo modo, le disgustaba lo que consideraba una exhibición vana e innecesaria de objetos religiosos; él no solía llevarlos ${ }^{67}$ y apercibía a quienes los portaban. ${ }^{68}$

\section{LA RELIGIOSIDAD POPULAR EN LAS COLONIAS. UNA RESISTENCIA DISCRETA A LAS MEDIDAS DE OLAVIDE}

Las posibilidades reales de resistencia de los colonos a las disposiciones del superintendente que afectaban a temáticas religiosas fueron muy escasas. Un sistema de gobierno tan marcadamente paternalista como el auspiciado por el Fuero de población de 5 de julio de 1767 confería unas enormes atribuciones a las autoridades neopoblacionales que, sin duda, llevaron a la población a tolerar o resistirse solo muy tímidamente. Aun así, constatamos que Olavide no siempre tuvo fácil el lograr que sus ideas se aceptaran; debiendo en muchas ocasiones tolerar algunas manifestaciones de religiosidad popular como un mal menor. Oponerse frontalmente a ellas quizá le habría causado más problemas que beneficios. Nos referimos, en concreto, al rezo del Rosario y establecimiento de cofradías y hermandades y a la exhibición en público de elementos y objetos de carácter religioso.

En lo que concierne al rezo del Rosario y al establecimiento de cofradías y hermandades, ${ }^{69}$ aunque estas últi-

65 Ibídem, pieza 3, testigo 146 (Juan Muñoz, 1777).

66 Ibídem, pieza 2, testigo 46 (fray Romualdo de Friburgo, 1775); pieza 3, testigo 101 (Jerónimo de Guillenea, 1777).

67 Ibídem, pieza 2, testigo 56 (Pedro de Vera, 1775); pieza 3, testigo 101 (Jerónimo de Guillenea, 1777) y testigo 141 (Juan Lanes y Duval, 1777). El capellán mayor de las Nuevas Poblaciones de Sierra Morena indica que nunca ha visto a Olavide llevar consigo el rosario.

68 Ibídem, pieza 3, testigo 150 (José Tomás Stefani, 1776). Olavide censuraba la ostentación de símbolos religiosos que hacía en público Baltasara Lancy, mujer del subdelegado Miguel de Ondeano.

69 Durante el siglo XVIII las autoridades civiles españolas, con la habitual colaboración de los obispos, trataron de regular y establecer límites a la religiosidad popular que se manifestaba a través de cofradías y hermandades; especialmente en lo que a supersticiones y gastos excesivos se refería (Arias de Saavedra Alías y López-Guadalupe Muñoz 2002; Álvarez Santaló et al. 1991). Al objeto de recabar información mas pudieron ser frenadas durante toda la etapa en la que Olavide permaneció al frente de las nuevas colonias, ${ }^{70}$ pues siempre se argumentó que eran lesivas para la economía familiar de los colonos y que requerían forzosamente, incluso las dedicadas al Santísimo Sacramento, ${ }^{71}$ autorización previa del Consejo de Castilla para su establecimiento, ${ }^{72}$ no ocurrió lo mismo con el Rosario. El que se desarrollaba dentro de las iglesias nunca supuso mayor problema, de ahí que el capeIlán mayor de La Carolina incentivase su establecimiento a través de un artículo contenido en una de las instrucciones que dirigió en 1769 a todos los capellanes de las colonias de Sierra Morena; ${ }^{73}$ en cambio, los que discurrían por la vía pública no tuvieron la misma fortuna pues, como manifestó ese mismo año a fray Marcos de Hornillos, capellán en La Carlota, Olavide pensaba «que el Rosario cantado por las calles era escandaloso y causa de las estafas en las limosnas que se pedían para ello.$^{74}$ Tan consecuente era con su pensamiento que muchos de los que lo trataron afirmaron que nunca lo vieron rezar o llevar el rosario consigo. ${ }^{75} \mathrm{El}$ desarrollo de esta práctica, por tanto, solo pudo tener lugar bien aprovechando su ausencia, como cuando el capellán suizo que acompañó a Pérez Valiente en su visita de inspección de 1769 instituyó la devoción del Santo Rosario, ${ }^{76}$ o bien en horarios y contextos discretos que, por su poca capacidad de convocatoria, fueron tolerados. ${ }^{77}$ Sabemos, en este sentido, que en ciertas épocas del año se celebraba en la capital de Sierra Morena un Rosario del Alba al que acudían sobre todo extranjeros pues Olavide recriminaba que tomaran parte en este a algunos de los pocos españoles que lo hacían, caso de su secretario Manuel Lázaro de la Vega. ${ }^{78}$

Las peticiones realizadas al superintendente por los religiosos de las nuevas colonias en favor de la práctica de este Rosario, al igual que solicitando el establecimiento de cofradías, no dejaron de ser muy frecuentes durante toda su etapa de gobierno. No obstante, pudo esquivarlas siempre

sobre estos excesos y abundantes gastos en las fiestas se realizaron interrogatorios en cada diócesis, los cuales pueden consultarse en el AHN. Por ejemplo, las correspondientes a la diócesis de Córdoba se conservan en AHN, Consejos, leg. 7091.

70 Un detallado y reciente análisis del origen y desarrollo de las cofradías y hermandades en las Nuevas Poblaciones de Sierra Morena y Andalucía durante la etapa foral puede verse en Pérez Fernández y Hamer Flores 2019.

71 AHN, Inquisición, leg. 1866, pieza 2, testigo 67 (Francisco de la Coba, 1776).

72 AGS, Secretaría y Superintendencia de Hacienda, leg. 499, doc. 62. Carta de Juan Lanes y Duval a Miguel de Ondeano, 9 de febrero de 1777, y carta de Miguel de Ondeano a Juan Lanes y Duval, 15 de febrero de 1777.

73 AHN, Fondos Contemporáneos, Gobernación, leg. 328, exp. 20. Lanes Duval estableció que todas las noches, después de oraciones, para que pudieran asistir las gentes del campo cuando volvían a sus casas, los capellanes rezaran en sus iglesias el rosario y letanía de María Santísima con la antífona Sub tuum praesídium confugimus y la oración De tempore.

74 AHN, Inquisición, leg. 1866, pieza 2, testigo 78 (fray Marcos Hornillos, 1769).

75 Ibídem, pieza 2, testigo 56 (Pedro de Vera, 1775); pieza 3, testigo 101 (Jerónimo de Guillenea, 1777).

76 Ibídem, pieza 3, testigo 82 (Francisco Antonio Henseler, 1776).

77 Ibídem, pieza 3, testigo 82 (Francisco Antonio Henseler, 1776). Finalizada la visita de inspección, Pablo de Olavide no suprimió estas devociones al Santo Rosario, pero sí prohibió que se acompañara de música.

78 Ibídem, pieza 3, testigo 81 (fray Pedro de Madrid, 1777). 
pidiéndoles paciencia y trasladando esa decisión hacia el futuro, cuando las colonias estuvieran suficientemente radicadas, pues defendía que todavía no era el momento para establecerlos. ${ }^{79}$

Por otro lado, la exhibición en público de objetos o elementos de temática religiosa también contó con unas fuertes restricciones. A veces, la discreción facilitó el poder burlarlas, pero en otras no fue posible. Por ejemplo, la ausencia de altares en la iglesia de La Carolina movía a algunas mujeres a llevar desde sus casas algunos cuadritos de la Virgen de los Dolores, del Carmen y San Antonio que ponían en el altar con sus velas para que se les dijesen misas; $; 0$ iniciativa para la que necesariamente contaron con la complicidad de parte del clero para que pudiera llevarse a término sin injerencias externas. No obstante, en otras ocasiones no hubo tanta suerte. En la celebración de la fiesta de difuntos de 1773 la iniciativa de un grupo de alemanas de colocar velas para que estuvieran encendidas durante los oficios no contó en el visto bueno de un dependiente de Olavide, que no dudó en apagarlas. Proceder que fue contestado por este grupo de mujeres, que al finalizar la misa clamaron en la plaza de la iglesia contra esta acción. ${ }^{81}$ Del mismo modo, los valencianos que vivían en Sierra Morena trataron de establecer en ella el culto a San Antonio, queriendo visitarlo en la iglesia todos los martes y los viernes a San Francisco de Paula, encontrando de nuevo un rechazo frontal por parte de las autoridades al indicarles el superintendente que no hacía falta visitar a los santos y que podían rezar en sus casas; incluso se les impidió la realización de una fiesta a san Antonio para la que algunos devotos ya habían costeado un simpecado y faroles con los que pretendían sacar el Rosario por las calles. ${ }^{82}$

Pero por si todo esto no era suficiente, el superintendente también impedía la venta de objetos religiosos en las colonias $^{83} \mathrm{y}$, además, trataba de contener toda manifestación religiosa que se exteriorizase en establecimientos abiertos al público. ${ }^{84}$ Entre estas últimas destacaban las estampas religiosas que, aunque habitualmente se colocaban en la parte exterior de las puertas y en las pareces de las casas, el alguacil mayor las ordenaba retirar ${ }^{85}$ o simplemente desaparecían sin que pudiera saberse quién los había arranca-

79 Ibídem, pieza 3, testigo 104 (Miguel de Ondeano, 1777).

80 Ibídem, pieza 3, testigo 110 (Francisca Hurtado, 1777).

81 Ibídem, pieza 3, testigo 100 (Juan Adam Spies, 1777).

82 Ibídem, pieza 2, testigo 74 (José Rodríguez, 1776).

83 Disponemos de algunos testimonios en este sentido. En 1773 Olavide negó su permiso para que un anciano vendiera un domingo, para poder obtener algunos ingresos, imágenes y crucifijos a los colonos (AHN, Inquisición, leg. 1866, pieza 3, testigo 134: Jacinto Muñoz, 1777). Dos años más tarde, el alguacil mayor echó de La Carolina a un hombre que vendía libros sagrados y estampas (Ibídem, pieza 3, testigo 127: Rodolfo de León, 1777; y testigo 141: Juan Lanes y Duval, 1777).

84 Ibídem, pieza 3, testigo 138 (Antonio Capmany, 1777). Algunos artesanos tenían estampas de temática religiosa en sus tiendas, habiendo ordenado Olavide que se quitase la que tenía un carretero.

85 El colono Jacinto Muñoz declara que había oído que hacía algunos años un colono español que vivía en el camino de Guarromán, cerca de esta colonia, tenía en la fachada de su casa una estampa de las benditas ánimas y un cepo para recoger dinero para pagarles misas, pero que el alguacil mayor los había arrancado y roto tras reñirle para que no continuase con esa práctica (Ibídem, pieza 3, testigo 134: Jacinto Muñoz, 1777). do. ${ }^{86}$ Aún más, incluso se apostó por una religiosidad estrictamente vinculada al espacio doméstico, considerando que estas prácticas no debían trasladarse ni percibirse en el espacio público. Un caso muy elocuente que ejemplifica bien esta medida lo encontramos en la afición a cantar canciones de temática religiosa del colono Jacinto Muñoz. Aunque acostumbraba a hacerlo en su casa, recibió por ello varios apercibimientos por parte del alguacil mayor de La Carolina que, dicho sea de paso, poco influyeron en su costumbre pues siguió haciéndolo. En 1773, mientras vivía en la calle Mayor, cantaba una relación en versos de los misterios de la Encarnación, concretamente una parte, según decía, del Evangelio de San Lucas, ${ }^{87}$ cuando Chávarri entró a su casa y le ordenó dejar de cantar; y en 1777, coincidiendo con su onomástica, cantaba en la casa en la que ahora residía, junto a la plaza de Toros, el Padrenuestro y el Ave María glosados para las benditas ánimas cuando el mismo alguacil mayor pasó y de nuevo le indicó que callase. ${ }^{88}$

En otro orden de cosas, los eclesiásticos de las Nuevas Poblaciones tampoco dudaron en desafiar, en la medida de lo que era posible para unos religiosos que dependían de unas asignaciones que procedían de la Real Hacienda, parte de las disposiciones que Olavide adoptó en el campo de la religión. Junto a cuestiones generalizadas como la queja porque se prohibió el toque de campanas para la mayor parte de los oficios religiosos, especialmente en lo que a entierros se refería, ${ }^{89}$ hubo resistencias mucho más específicas como la liderada por el capuchino alemán fray Romualdo de Friburgo. Consciente de que Olavide trataba de eliminar el culto a San Juan de la Cruz, ${ }^{90}$ el religioso no dudó en incentivarlo con un grupo de alemanas y españolas que acudía a la ermita homónima que se levantaba a escasa distancia del casco urbano de La Carolina. Durante mucho tiempo dijo misa en ella los viernes, lo que encolerizó al superintendente que, según el capuchino, amenazó con destruir la ermita. Al parecer, retiró de ella una vidriera que hizo colocar en su palacio, ${ }^{91}$ con lo que los fieles quedaron expuestos a las inclemencias meteorológicas, e incluso ordenó talar dos grandes pinos que se decía que databan del momento de su fundación. ${ }^{92}$ Por otro lado, este religioso también incumplió

86 Jacinto Muñoz colocó en 1776 en la puerta de su casa con tachuelas una estampa de la Virgen del Carmen, pero un día al volver por la noche se la encontró arrancada y, por más que preguntó, no pudo encontrar ningún testigo de los hechos, aunque sospechaba que esta acción era obra del alguacil mayor, porque con anterioridad este había arrancado la que había puesto en la suya una mujer conocida como la «tuerta granadina» (Ibídem, pieza 3, testigo 133: María Teresa Hurtado; y testigo 134: Jacinto Muñoz, 1777).

87 En concreto, los versos que cantaba eran los siguientes: «Reyes de Libonia y Tebas / que sobre la ruda cumbre / cima del délfico monte / sacrificios y perfumes / venís a ofrecer al templo / del Monarca de las luces / yo soy cristiano y de Cristo/ sigo las palabras, lumbre / de la fe». Este fragmento se correspondía con una comedia versificada del siglo XVII, obra de Fernando de Zárate y Castronovo (Cuenca, 1600 - Sevilla, 1663) y titulada De médico pintor San Lucas (1675).

$88 \mathrm{AHN}$, Inquisición, leg. 1866, pieza 3, testigo 134 (Jacinto Muñoz, 1777).

89 Ibídem, pieza 2, testigo 56 (Pedro de Vera, 1775) y testigo 57 (Francisco de la Coba, 1776); pieza 3, testigo 100 (Juan Adam Spies, 1777), testigo 101 (Jerónimo de Guillenea, 1777) y testigo 102 (Juan Calvet, 1777).

90 Ibídem, pieza 3, testigo 101 (Jerónimo de Guillenea, 1777).

91 Ibídem, pieza 2, testigo 46 (fray Romualdo de Friburgo, 1775).

92 Ibídem, pieza 3, testigo 138 (Antonio Capmany, 1777). 
siempre que pudo la orden de que los religiosos no acompañasen al cortejo fúnebre con cruz y ciriales desde la iglesia hasta el cementerio de la capital de las colonias de Sierra Morena. ${ }^{93}$

\section{CONCLUSIONES}

La imprudente combinación de un pensamiento avanzado y rupturista con una personalidad impulsiva e impaciente hizo que la trayectoria vital de Pablo de Olavide se caracterizara por frecuentes tensiones y enfrentamientos con todos aquellos que no compartían su modo ilustrado de ver el mundo. Su proximidad a destacados personajes de la alta administración del Estado, muchos de los cuales compartían parte de su ideario ilustrado y reformista, le permitieron disfrutar de una destacada posición social y ejercer importantes puestos de gobierno; a pesar de lo cual no pudo evitar pisar la cárcel a su llegada a la península ibérica. De ahí que no constituya un hecho excepcional el que aprovechara las enormes competencias que recibió para poner en marcha las Nuevas Poblaciones de Sierra Morena y Andalucía con el objetivo de hacer realidad en ellas buena parte de sus ideas de reforma, un hecho facilitado por la propia circunstancia de haberse concebido esa colonización agraria como una experiencia en la que ensayar un nuevo modelo social en el que no estarían presentes aquellos elementos que los ilustrados españoles consideraban lacras para el progreso de la sociedad y de la economía.

De este modo, entre 1767 y 1776, fecha esta última en la que fue encarcelado por la Inquisición, Olavide dio rienda suelta a sus ideas en esas nuevas colonias. Un espacio que ofrecería menos resistencia que Madrid y, sobre todo, Sevilla a todos los cambios que promovió en tan poco tiempo. Es por ello por lo que estas Nuevas Poblaciones constituyen el mejor ejemplo para entender el papel que Olavide concedía a la Iglesia en la sociedad y el modelo de religiosidad popular que consideraba más adecuado. Un análisis para el que hemos empleado cuatro indicadores principales: las iglesias y sus advocaciones, los altares y la dotación para el culto, los oficios religiosos y la religiosidad en el espacio público. Hemos podido comprobar, de este modo, que nuestro personaje hizo todo lo posible para que las iglesias estuvieran dedicadas a la Inmaculada Concepción, impidiendo que hubiera más de un altar o dos en cada iglesia y, por tanto, evitando el culto a los santos. Decisiones que llevaron a algunas protestas, aunque siempre tímidas, de los colonos y de los eclesiásticos.

Muy diferente sería el caso de su intromisión en los oficios religiosos. Sus disposiciones acerca de la forma de vestir de las mujeres, prohibiendo ropas que cubriesen sus cabezas y hombros, al igual que la introducción durante la misa de una serie de cánticos para los que compuso varias canciones, contribuyeron a tensar aún más el trato que mantenía con algunos religiosos de las nuevas colonias. Pero si quedaba algún resquicio para evitar el conflicto, la radical oposición del limeño a que se desarrollasen actividades religiosas en el espacio público (como procesiones o el rosario cantado) y a que existiesen cofradías religiosas lo cerró definitivamente. El fraile capuchino alemán fray Ro-

93 Ibídem, pieza 3, testigo 99 (Lorenzo Felder, 1777). mualdo de Friburgo, destinado para la asistencia espiritual de los colonos alemanes de La Carolina, no dudó en liderar una verdadera campaña de delaciones contra el limeño ante la Inquisición.

Todas estas medidas, aunque supusieron la plasmación práctica en parte del territorio español de algunas ideas y medidas de índole religiosa demasiado avanzadas para la sociedad del siglo XVIII, tuvieron por este mismo motivo muy corto recorrido en esas nuevas colonias. Con la detención y posterior condena inquisitorial de Olavide en 1778 , la práctica totalidad de las iniciativas que hemos analizado en este trabajo fueron rechazas para abrazar con gran rapidez las costumbres y prácticas en materia religiosa existentes en cualquier localidad de su entorno. La imprudencia y prisa del limeño por implantar su modelo y el escaso deseo de cambio en estos asuntos mostrado por la sociedad neopoblacional impidieron finalmente que arraigara un interesante experimento que trató de llevar la práctica religiosa dieciochesca a una dimensión más personal; más esencia y menos apariencia.

\section{BiBLIOGRAFÍA}

Alcázar Molina, Cayetano. 1930. Las colonias alemanas de Sierra Morena (Notas y documentos para su historia). Madrid: Universidad de Murcia.

Álvarez Santaló, León Carlos, José Enrique Ayarra Jarne, Juan Miguel González Gómez, José Roda Peña y José Sánchez Herrero. 1991. Las cofradías de Sevilla en el siglo de las crisis. Sevilla: Secretariado de Publicaciones de la Universidad de Sevilla.

Arias de Saavedra Alías, Inmaculada y Miguel Luis López-Guadalupe Muñoz. 2002. La represión de la religiosidad popular. Crítica y acción contra las cofradías en la España del siglo XVIII. Granada: Universidad de Granada.

Arocena, Félix María. 2006. El altar cristiano. Barcelona: Centre de Pastoral Litúrgica.

Atienza López, Ángela. 2012. «El clero regular mendicante frente al reformismo borbónico. Política, opinión y sociedad». Obradoiro de Historia Moderna 21: 197-217.

Barrio Gozalo, Maximiliano. 2000. «Reforma y supresión de los regulares en España al final del Antiguo Régimen (1759-1836)». Investigaciones Históricas. Época Moderna y Contemporánea 20: 89-118.

Bolzern, Rudolf. 1988. "La emigración suiza a las Nuevas Poblaciones de Sierra Morena y Andalucía: rasgos generales y primeros resultados de un proyecto de investigación». En Carlos III y las Nuevas Poblaciones, edición de Miguel Avilés Fernández y Guillermo Sena Medina, vol. 1, 213-222. Córdoba: Universidad de Córdoba.

Bolzern, Rudolf. 1991. «Josef Anton Jauch, caventurero y logrero o reclutador profesional?». En Nuevas Poblaciones en la España Moderna, edición de Miguel Avilés Fernández y Guillermo Sena Medina, 253-259. Córdoba: UNED.

Cañas Murillo, Jesús. 2004. «Inquisición y censura de libros en la España de Carlos III: la real cédula de junio de 1768». Anuario de Estudios Filológicos 27: 5-11.

Caro López, Ceferino. 2004. "Censura gubernativa, Iglesia e Inquisición en el siglo XVIII». Hispania Sacra LVI, 114: 479-511. https://doi. org/10.3989/hs.2004.v56.i114.132

Castro, Concepción de. 1996. Campomanes. Estado y reformismo ilustrado. Madrid: Alianza Editorial.

Defourneaux, Marcelin. 1965. Pablo de Olavide, el afrancesado. México: Editorial Renacimiento.

Delgado Barrado, José Miguel. 2018. «El Fuero de las Nuevas Poblaciones a examen cuantitativo». En Congreso Internacional Nuevas Poblaciones de Sierra Morena y Andalucía y otras colonizaciones agrarias en la Europa de la llustración, coordinación Adela Tarifa 
Fernández, José Antonio Filter Rodríguez y Amparo Ruiz Olivares, 23-40. Jaén: Instituto de Estudios Giennenses.

Egido López, Teófanes. 1991. «El Regalismo en España». En Iglesia, sociedad y Estado en España, Francia e Italia (ss. XVIII al XX), edición de Emilio La Parra López y Jesús Pradells Nadal, 193-218. Alicante: Instituto de Cultura Juan Gil Albert.

Egido López, Teófanes. 2003. «Campomanes, regalismo y jesuitas». En Campomanes: doscientos años después, coordinación Dolores Mateos Dorado, 343-360. Oviedo: Universidad de Oviedo.

Espinalt García, Bernardo. 1787. Atlante español, o descripcion general geográfica, cronológica e histórica de España, por reynos y provincias; de sus ciudades, villas y lugares más famosos; de su población, ríos, montes, etc. Adornado de estampas finas que demuestran las vistas, perspectivas de todas las ciudades, trages propios que usa cada reyno y blasones que le son peculiares. Vol. 11. Madrid: En la Imprenta de Pantaleón Aznar.

Fernández Díaz, Roberto. 2004. Historia de España. 10: La sociedad del siglo XVIII. Las reformas pendientes y el pensamiento económico ilustrado. Madrid: Espasa-Calpe.

Fílter García, Alberto. 2018. Johann Kaspar von Thürriegel. Estudios y artículos. Sevilla: Ayuntamiento de Cañada Rosal.

Gómez Urdáñez, José Luis. 2015. «Con la venia de Carlos III. El castigo ejemplar de Olavide, consecuencia de la venganza de Grimaldi contra el conde de Aranda». Vegueta. Anuario de la Facultad de Geografía e Historia 15: 373-400.

Hamer Flores, Adolfo. 2009a. La Intendencia de las Nuevas Poblaciones de Sierra Morena y Andalucía, 1784-1835. Gobierno y administra ción de un territorio foral a fines de la Edad Moderna. Córdoba: Universidad de Córdoba.

Hamer Flores, Adolfo. 2009b. Las Nuevas Poblaciones de Andalucía y sus primeros colonos (1768-1771). Madrid: Bubok Publishing.

Hamer Flores, Adolfo. 2010. «Las últimas voluntades de Johann Kaspar von Thürriegel, coronel bávaro al servicio de Carlos IIl». Ámbitos. Revista de Estudios de Ciencias Sociales y Humanidades 23: 113119.

Hamer Flores, Adolfo, ed. 2018. Legislación Histórica Neopoblacional. Disposiciones normativas emanadas del poder central en las Nuevas Poblaciones de Sierra Morena y Andalucía (1767-1835). Madrid: Bubok Publishing.

Hamer Flores, Adolfo y Francisco José Pérez Fernández. 2019. «Visualizando el poder real. Toponimia y heráldica en las Nuevas Poblaciones de Sierra Morena y Andalucía». Investigaciones Históricas. Época Moderna y Contemporánea 39: 257-292. https://doi. org/10.24197/ihemc.39.2019.257-292

Hera Pérez-Cuesta, Alberto de la. 2014. «El regalismo borbónico». En La Iglesia en la Historia de España, dirección José Antonio Escudero López, 645-659. Madrid: Fundación Rafael del Pino - Marcia Pons.

Marín López, Javier. 2018. "Cultura musical y Nuevas Poblaciones». En Congreso Internacional Nuevas Poblaciones de Sierra Morena y Andalucía y otras colonizaciones agrarias en la Europa de la Ilus- tración, coordinación de Adela Tarifa, José Antonio Fílter y Amparo Ruiz, 1523-1547. Jaén: Instituto de Estudios Giennenses.

Martínez Shaw, Carlos. 1996. El Siglo de las Luces. Las bases intelectuales del reformismo. Madrid: Historia 16.

Mestre Sanchís, Antonio. 1991. «Reflexiones sobre el regalismo y reforma de la Iglesia en el reinado de Carlos III». En Cum vobis pro vobis. Homenaje de la Facultad de Teología San Vicente Ferrer, de Valencia, al Excmo. y Rvdmo. Dr. D. Miguel Roca Cabanellas en sus bodas de plata episcopales, coordinación Ramón Arnau-García y Roberto Ortuño Soriano, 695-707. Valencia: Facultad de Teología San Vicente Ferrer.

Mestre Sanchís, Antonio. 2004. «llustración, regalismo y jansenismo». En Historia de España en la Edad Moderna, coordinación Alfredo Floristán Samanes, 715-740. Barcelona: Ariel.

Palacios Alcalde, María. 1988. "Mobiliario litúrgico distribuido a las Iglesias de las Nuevas Poblaciones de Sierra Morena». En Carlos III y las Nuevas Poblaciones, edición de Miguel Avilés Fernández y Guillermo Sena Medina, vol. 3, 189-214. Córdoba: Universidad de Córdoba.

Perdices de Blas, Luis. 1992. Pablo de Olavide (1725-1803), el ilustrado. Madrid: Editorial Complutense.

Pérez Fernández, Francisco José. 2015. Cancionero popular de Aldeaquemada. Folclore de las Nuevas Poblaciones de Sierra Morena. Jaén: Diputación de Jaén.

Pérez Fernández, Francisco José. 2019a. «San Antón y el Pelotero de Arquillos: dos claves de la religiosidad popular en una colonia de Sierra Morena». Ámbitos. Revista de Estudios de Ciencias Sociales y Humanidades 41: 35-47.

Pérez Fernández, Francisco José. 2019b. Colonos y propietarios de las Nuevas Poblaciones de Sierra Morena durante la Edad Moderna. Tesis Doctoral inédita. Universidad de Jaén.

Pérez Fernández, Francisco José y Adolfo Hamer Flores. 2019. «llustración y religiosidad popular en las Nuevas Poblaciones de Sierra Morena y Andalucía: las cofradías que Olavide no quiso». Vegueta. Anuario de la Facultad de Geografía e Historia 19: 667-684.

Perrupato, Sebastián Domingo. 2018. «Pensar la reforma agraria desde la educación. Nuevas reflexiones en torno al discurso sobre la educación de los labradores de Rodríguez de Campomanes». Stvdia Historica. Historia Moderna 40 (1): 405-426.

Rey Castelao, Ofelia. 1992. Poder y privilegios en la Europa del siglo XVIII. Madrid: Editorial Síntesis.

Sánchez-Batalla Martínez, Carlos. 1998-2003. La Carolina en el entorno de sus colonias gemelas y antiguas poblaciones de Sierra Morena. Prehistoria a 1835. 4 vols. Jaén: Caja Rural de Jaén.

Valenciana, Ambrosio de. 1924. El director perfecto y el dirigido Santo. Correspondencia epistolar del B. Diego José de Cádiz con el V. P. Maestro Francisco Javier González y viceversa. Sevilla: Imprenta de la Divina Pastora.

Weiss, Joseph. 1907. Die deutsche Kolonie an der Sierra Morena und ihr Gründer Johann Kaspar von Thürriegel, ein bayerischer Abenteurer des 18 Jahrhunderts; ein Beitrag zur Geschichte unseres VoIkstums im Auslande. Köln: J.P. Bachem. 
